\title{
Translation of social and occupational functioning scale for epilepsy into Portuguese - Brazil
}

\author{
Tradução da escala de funcionamento ocupacional e social para pessoas com epilepsia \\ para português - Brasil \\ Patricia Fernandes ${ }^{1}$, Carolina Meiga ${ }^{1}$, Anderson de Castro Peres ${ }^{2}$, Cesar Augusto Taconeli², Renato Nickel', \\ Carlos Silvado ${ }^{3}$
}

\begin{abstract}
Epilepsy has important consequences on functionality and social activities. There are few evaluation tools for this purpose. This study aimed to translate the Social and Occupational Functioning Scale for Epilepsy. It is a translation study, for which Beaton et al's. guidelines were used. Sixty patients over 18 years of age, with a confirmed diagnosis of epilepsy, were evaluated. The analysis of internal consistency (Cronbach's alpha) showed values between 0.55 and 0.72 associated with the original dimensions of the instrument, while the five dimensions identified by the results of an exploratory factor analysis showed values between 0.60 and 0.68 , with different grouping of the structures of the original scale. Respondents had no difficulty answering the translated version of the Social and Occupational Functioning Scale for Epilepsy, but the statistics show the need for cultural adaptation to the Brazilian population.
\end{abstract}

Keywords: epilepsy; activities of daily living; translating.

RESUMO

A epilepsia traz importantes consequências na funcionalidade e nas atividades sociais. São escassos os instrumentos de avaliação para esta finalidade. Este estudo tem por objetivo realizar a tradução da Escala de Funcionamento Social e Ocupacional para Epilepsia - SOFSE. É um estudo de tradução, para o qual foram utilizadas as diretrizes de Beaton et al. (2000). Foram avaliados 60 sujeitos, acima de 18 anos com diagnóstico confirmado de epilepsia. A análise da consistência interna (alpha de Cronbach) apresentou valores entre 0,55 e 0,72 associados às dimensões originais do instrumento, enquanto as cinco dimensões identificadas pelos resultados de uma análise fatorial exploratória apresentaram valores entre 0,60 e 0,68, com agrupamento diferente da estrutura da escala original. Os entrevistados não apresentaram dificuldade para responder a versão traduzida da SOFSE, mas os resultados estatísticos mostram a necessidade de uma adaptação cultural para a população brasileira.

Palavras-chave: epilepsia; atividades cotidianas; tradução.

Epilepsy is a medical condition that has several consequences for the lives of individuals. Social and daily life difficulties are frequently experienced ${ }^{1}$.

Many people with epilepsy may not have disabilities, limitations or restrictions throughout life; others, on the other hand, may have their health and well being seriously harmed ${ }^{2}$.

A study conducted with patients with epilepsy from a university fourth level epilepsy center described the main difficulties encountered by people with difficult-to-control epilepsy in performing daily activities and socialization. Difficulties in domestic, self-care, educational and formal work activities, as well socialization problems, have been described as the most frequent, demonstrating that seizure control alone does not seem to be sufficient for the patient with epilepsy to have a good quality of life $\mathrm{e}^{3,4}$.

This information confirms the multidimensional impact of epilepsy on people's lives, culminating with functional and social problems ${ }^{5}$.

It is important to note that this impact may vary depending on the level of the country's socioeconomic development

1Universidade Federal do Paraná, Departamento de Terapia Ocupacional, Curitiba PR, Brasil;

Universidade Federal do Paraná, Departamento de Estatística, Curitiba PR, Brasil;

${ }^{3}$ Universidade Federal do Paraná, Hospital de Clínicas, Departamento de Medicina Interna, Curitiba PR, Brasil.

Correspondence: Patricia Fernandes; Rua Professor Lothario Meissner, 632 / Bloco Didático II da Saúde; 80210-170 Curitiba PR, Brasil;

E-mail: patriciafernandes.to@gmail.com

Conflict of interest: There is no conflict of interest to declare.

Received 10 November 2016; Received in final form 13 February 2017; Accepted 15 April 2017. 
and culture. Personal issues, such as years of education; and environmental issues, such as attitudes (prejudices), services, systems and policies in relation to people with epilepsy, can interfere with the quality of life.

The attention on the patient with epilepsy aims mainly at the control of seizures, with discussions on functionality emerging in recent years. For quality of life, labor and employment should become an essential discussion.

Thus, knowing the restrictions on social participation, limitations of activities, and the inability and functionality experiences of a person with epilepsy, can help with the development of intervention strategies and the structuring of services and policies for this population.

Aiming at assessing the functionality of people with epilepsy, Wang et al. ${ }^{6}$ developed the Social and Occupational Functioning Scale for Epilepsy (SOFSE), which is a scale developed in Chinese and English and validated for use in the Chinese language only.

In the tool, 30 items related to the main functional difficulties experienced by individuals with epilepsy are compiled. The scale is organized into six dimensions: interpersonal relationships; communication; social activities; leisure activities; instrumental living skill; and occupation, which is divided into: A (paid work) and B (unpaid work). The scale is self-administered and the score ranges from 0 to 100, where the higher the value, the better the functional status of the individual ${ }^{6}$.

Our goals were to: 1 . Translate the SOFSE into Brazilian Portuguese; 2. Apply the Brazilian Portuguese SOFSE version in a group of patients with temporal lobe epilepsy.

\section{METHODS}

This was a study conducted with a convenience sample of 60 adult individuals being treated at the Epilepsy Outpatient Clinic of the Clinics Hospital of the Federal University of Parana, from March to November 20147.

The study was conducted in accordance with resolution 466/2012 MS/CNS, and was approved by the Ethics in Research Committee of the Clinics Hospital of the Federal University of Parana under number 505.320.

The sample comprised literate individuals, aged 18 to 59 years old, with a confirmed diagnosis of temporal lobe epilepsy and no other associated health condition capable of compromising their functionality beyond the epilepsy itself.

The approach consisted of applying a semi-structured questionnaire to collect sociodemographic data, and application of the translated version of the SOFSE.

The process of translation into Brazilian Portuguese started after the authorization of the authors of the SOFSE and followed the guidelines of Beaton et al. ${ }^{8}$ The steps of the translation process are presented in the Figure.

After completing the translation, we included questions at the end of the scale to check the understanding of the respondents with respect to the items in the scale.

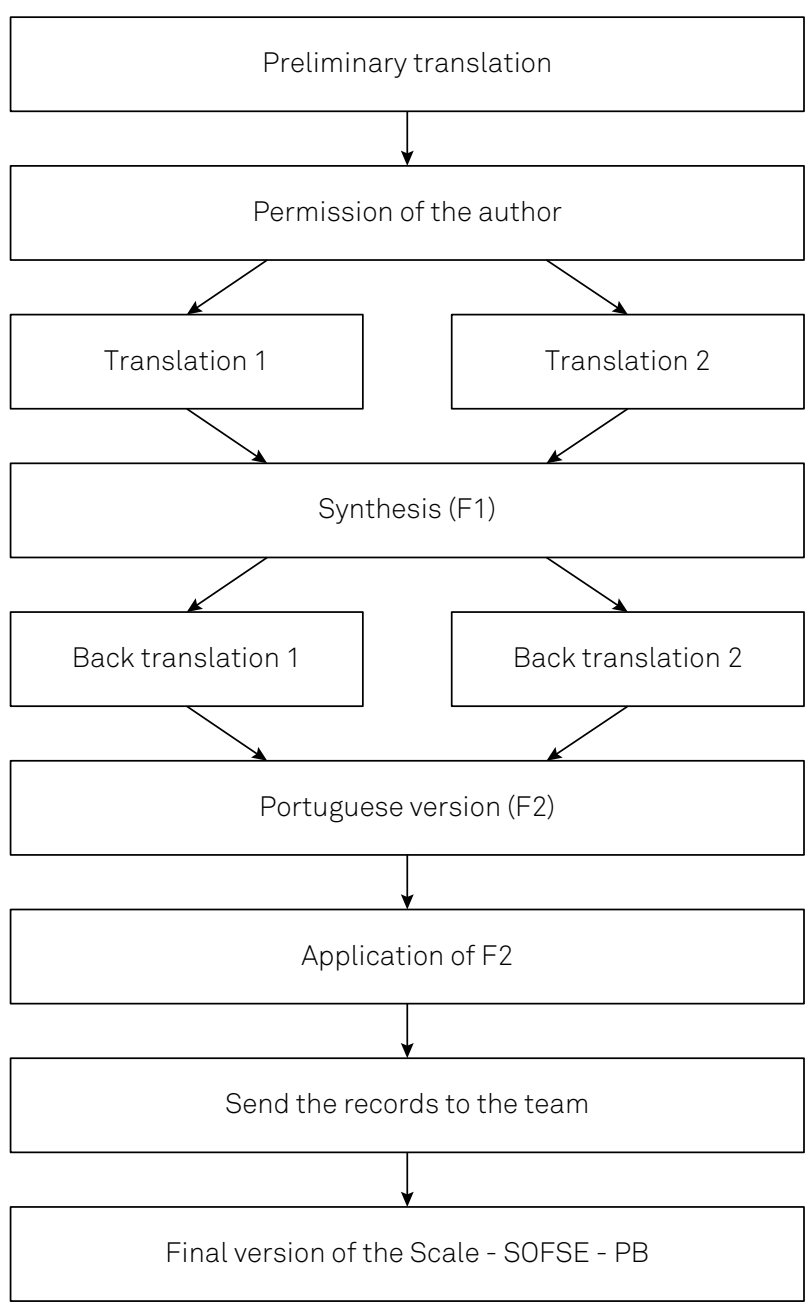

Figure. Translation process steps

Also, as part of the SOFSE process of adaptation for use in Brazil, in dimension 4 "leisure activities", the patients were questioned about the practice of other leisure activities, which were not included in this dimension.

As part of the adaptation process, the term "Qi gong", included in dimension 3 "social activities", was replaced by "physical activity", after being discussed with the committee seeking to maintain experiential equivalence, taking into account the Brazilian culture. The goal was to capture the experience of daily life. Often a common activity in one culture may not be experienced in another, as is the case of this particular activity (Qi gong), which is not common in Brazil ${ }^{8}$.

Regarding the content of the SOFSE, the answers to the most of the questions are related to the frequency of certain activities ${ }^{6}$. Only one of the dimensions, dimension 5 , required two answers to each question: an answer related to the ability to perform the activity and the other related to its frequency. Thus, for statistical analysis in this dimension of the scale, it was decided to consider only the answers regarding the frequency of the activities, following the same pattern of the responses of other dimensions evaluated. The Brazilian version of the SOFSE (SOFSE-PB) is shown in Appendix 1. 
To analyze the psychometric qualities of the translated version, we used Cronbach's alpha coefficient to evaluate the consistency of the SOFSE dimensions and the exploratory factor analysis to identify factors based on correlation of the items ${ }^{9}$. To assess the adequacy of the factorial analysis of the sample, the coefficient of Kaiser-Meyer-Olkin (KMO) was used, and the Bartlett test was used to test the hypothesis of null correlation between items ${ }^{10}$. The R software and the psych package were used to perform the analysis.

\section{RESULTS}

Fifty percent of the 60 patients of the sample were male and the average age was 39.31 years old ( \pm 9.87 years).

In terms of clinical data, there was no significant difference in the laterality of epilepsy (right, left temporal and bitemporal lobe epilepsy). Table 1 shows the sociodemographic and clinical characteristics of the respondents.

In the application of the translated version of the SOFSE, by including the responses to the question included at the end of the scale, we ensured that none of the patients had difficulty in understanding the terms or the words in the questions.

The lowest average scores were found in the dimensions "leisure activities", "occupation" and "social activities",

Table 1. Sociodemographic and clinical data.

\begin{tabular}{lc}
\hline Condition of the 60 patients & $\mathrm{N}(\%)$ \\
\hline Schooling & $23(38.3 \%)$ \\
\hline Some elementary & $5(8.3 \%)$ \\
\hline Elementary school completed & $7(11.6 \%)$ \\
\hline Some high school & $17(28.3 \%)$ \\
\hline High school graduate & $2(3.3 \%)$ \\
\hline Some college & $3(5 \%)$ \\
\hline Bachelor's degree & $3(5 \%)$ \\
\hline Postgraduate studies & \\
\hline Marital status & $21(35 \%)$ \\
\hline Single (never been married) & $20(33.3 \%)$ \\
\hline Married & $11(18.3 \%)$ \\
\hline Living common law & $7(13.2 \%)$ \\
\hline Separate/divorced & \\
\hline Occupation & $20(33.3 \%)$ \\
\hline Paid employee & $8(13.3 \%)$ \\
\hline Self-employed & $10(16.6 \%)$ \\
\hline Retired & $14(23.2 \%)$ \\
\hline Unemployed & $8(13.2 \%)$ \\
\hline Others & $27(45 \%)$ \\
\hline Laterality of epileptic focus & $25(41.3 \%)$ \\
\hline Right & $8(13.3 \%)$ \\
\hline Beft & $23(38.3 \%)$ \\
\hline Nes & $37(61.6 \%)$ \\
\hline
\end{tabular}

indicating a lower degree of participation in these activities. Table 2 shows the results.

For psychometric analysis of the SOFSE-PB, the internal consistency of the items was verified against the dimensions of the original version ${ }^{6}$, and the exploratory factor analysis was checked to verify the possibility of a better combination of items and, consequently, dimensions composed of items different from those observed in the original scale.

The statistical analyses of the six dimensions are presented separately. Table 3 shows the results of five dimensions and describes the results of dimension 6 (occupation). The division was because this had to be applied differently to two groups of patients: those who worked and those who did not work.

For the purpose of comparison, Table 3 shows the grouping of the variables according to the original dimensions of the instrument and the resulting grouping of the exploratory factor analysis. For the purpose of evaluation and comparison of the internal consistency of the dimensions for the two allocations, the values of Cronbach's alpha coefficient are shown using the responses of the participants of the study conducted in Brazil. The Bartlett's test of sphericity produced highly significant results, indicating the existence of non-null correlations between items. Additionally, a $\mathrm{KMO}=0.59$ was verified. The closer to 1 the value of KMO, the better the fit of the factor model to the data; the closer to zero, the worse it is, in the sense that the smaller the proportion of variation in the data is explained by the corresponding factors. In general, the use of factor analysis is inadvisable in the case of $\mathrm{KMO}<0.50^{11}$.

Considering the original SOFSE grouping, Cronbach's alpha results for dimensions 1 and 4 indicate low internal consistency (less than 0.60); dimensions 3 and 5 showed values between 0.60 and 0.70 , which are considered acceptable but to be evaluated with caution; and only dimension 2 had measures higher than 0.70, which guarantees better results ${ }^{12,13}$.

In the factor analysis, some variables were grouped in different dimensions from the original cluster, which can be seen in dimensions 2 and 5. When performing the internal consistency analysis, based on the grouping factor analysis, it was observed that the values of Cronbach's alpha do not indicate appropriate measures for clinical studies ${ }^{12}$.

Table 2. Averages and medians for the domains of Social and Occupational Functioning Scale for Epilepsy - SOFSE.

\begin{tabular}{lcc}
\hline Domains & Averages* & Medians* \\
\hline Interpersonal relationship & $77.39( \pm 19.00)$ & 77.23 \\
\hline Communication & $67.39( \pm 21.89)$ & 68.75 \\
Social activities & $62.43( \pm 21.64)$ & 59.99 \\
\hline Leisure activities & $47.21( \pm 28.97)$ & 49.99 \\
\hline Instrumental living skill & $77.58( \pm 20.45)$ & 85 \\
\hline Occupation & $60.22( \pm 30.78)$ & 64.99 \\
\hline Total & $58.41( \pm 12.95)$ & 58.68 \\
\hline *SOFSE Score: 0 - 100 points. \\
*Averages and medians referring to subjects' scores in the SOFSE domains: \\
0 to 100.
\end{tabular}


Table 3. Results exploratory factor analysis and cronbach's alpha.

\begin{tabular}{|c|c|c|c|c|}
\hline Dimensions & Original grouping (SOFSE) & Cronbach's Alpha & Grouping (SOFSE-PB) & Cronbach's Alpha \\
\hline 1 & ri1, ri2, ri3, ri4 & 0.563 & $\mathrm{co1}, \mathrm{co3}, \mathrm{co} 4$ & 0.675 \\
\hline 2 & $\mathrm{co} 1, \mathrm{co} 2, \mathrm{co} 3, \mathrm{co} 4$ & 0.702 & co2, as4, as5, la1, la2, hi3 & 0.608 \\
\hline 3 & as1, as2, as3, as4, as5 & 0.677 & hi1, hi2, hi4, hi5 & 0.672 \\
\hline 4 & la1, la2 & 0.553 & Ri1, ri2, ri3 & 0.637 \\
\hline 5 & hi1, hi2, hi3, hi4, hi5 & 0.668 & ri4, as1, as2, as3 & 0.613 \\
\hline Bartlett test & \multicolumn{4}{|c|}{$349,9826(p<0.001)$} \\
\hline $\mathrm{KMO}$ & \multicolumn{4}{|c|}{0.59} \\
\hline
\end{tabular}

SOFSE: Social and Occupational Functioning Scale for Epilepsy; ri: interpersonal relationships; co: communication; as: social activities; la: leisure; hi instrumental living skill; KMO: Kaiser-Meyer-Olkin. Original allocation, resulting from of the exploratory factor analysis in five dimensions and the corresponding values of Cronbach's Alpha.

The results of the internal consistency analysis (Cronbach's alpha) for dimension 6 (occupation) was 0.3406 for the group of patients who worked and 0.6948 for the group of patients who did not work. This result indicates that the group of patients who worked showed a low degree of internal consistency, and the group of patients who did not work showed results of internal consistency close to those indicated for clinical studies ${ }^{12}$.

For the group of workers of the same dimension mentioned above, the result of the KMO test was 0.49 , indicating that it is not advisable to carry out the factor analysis; and the result of the Bartlett test was 6.235763 (p-value: 0.7950817) indicating the absence of non-null correlations between items. For the group of patients who did not work, the loadings of the factor analysis ranged between 0.35 and 0.77 . The result of the KMO test was 0.59, indicating that it is advisable to carry out the factor analysis; and the result of the Bartlett test was 32.63357 (p-value: 0.0003), indicating the existence of non-null correlations between items. However, the factor analysis aims to achieve a better grouping of items in different factors and, in this case, in which there is only one factor (dimension 6 - occupation), the factor analysis becomes irrelevant. The loadings for each item of the scale are shown in Appendix 3.

And yet, in the same dimension mentioned above, one of the variables in this component, in both groups (workers and non-workers), differs from the others because it is the only one represented by a dichotomous variable. This, added to the sample size, may have affected the results of the internal consistency analysis.

\section{DISCUSSION}

Because of the implications of epilepsy in the lives of the patients, the study of functionality is fundamental. Some authors ${ }^{3,4,14}$ have already addressed this issue. However, when it comes to assessment tools, the SOFSE was the first scale developed with the purpose of measuring functionality in epilepsy. Thus, the SOFSE-PB can collaborate in the assessment of epilepsy impact on the daily life of Brazilian patients.
The SOFSE-PB can be considered easy to apply as the respondents had no difficulty in understanding and responding to the questions. The scale includes different activities that are often affected by this health condition and considers several factors that often affect the participation of these patients in the activities evaluated.

Concerning the application of the SOFSE-PB, the respondents had lower result averages in the dimensions of "leisure activities", "occupation" and "social activities". It is known that individuals with epilepsy often face barriers in carrying out these activities. Several studies have reported labor as the activity most affected by epilepsy ${ }^{4,14,15,16,17,18}$. And Han et al. ${ }^{19}$ stated that the fear of seizures is among the main barrier to the performance of leisure activities.

Studies have also pointed out that people with epilepsy face severe difficulties in engaging in social activities and often have the right of social participation denied ${ }^{14}$. In the study by Motamedi et al. ${ }^{20}$, the impact on social life and activities was one of the main complaints of the study participants. Kobau et al. ${ }^{21}$ claimed that adults with epilepsy reported more difficulties in social participation than adults without epilepsy.

The total score average was $58.41( \pm 12.95327)$, indicating a low degree of functionality of the patients. Koponen et al. ${ }^{22}$ stated that social functioning was affected by the degree of seizure control and Nickel et al. ${ }^{3}$ found that epilepsy lead to limitations in many aspects of the life of the patient, directly interfering with functionality.

Koponen et al. ${ }^{22}$ felt that a better performance in the early stages of life was related to a favorable subsequent intellectual, social and functional development. Therefore, the use of a tool such as the SOFSE-PB to identify the functional limitations of people with epilepsy, followed by a therapeutic approach to correct or mitigate this commitment, initiated as early as possible by a multidisciplinary team, can improve the functionality of a person with epilepsy and promote the best performance possible in their activities.

In the results of the psychometric analysis of the SOFSE-PB, the internal consistency coefficient for most dimensions presented was low or acceptable. Only one 
component had an appropriate degree of internal consistency for clinical studies ${ }^{12}$, indicating that the overall dimensions do not show satisfactory consistency.

On the other hand, the original version ${ }^{6}$, published in 2013, showed internal consistency coefficients greater than 0.7 , which are considered suitable for clinical studies ${ }^{12}$.

The exploratory factor analysis also resulted in a grouping different from that of the original ${ }^{6}$ scale, especially for the dimensions 2 and 5, in which items in different dimensions overlap. In dimension 2 , one communication item, two social activities, two leisure and instrumental living skill were grouped. In dimension 5, one interpersonal relationship item was grouped with three items of social activities.

Thus, the results of the psychometric analysis of the SOFSE-PB indicate the need for an adjustment of the scale for a specific population, in order to check for better consistency results. Another factor that must be considered is the sample size and limited number of questions in some dimensions of the scale, which may have influenced the results of the analyses.

In conclusion, the SOFSE-PB showed itself to be a brief, comprehensive and easy-to-use tool for measuring the functional condition of the person with epilepsy in the different activities that are more frequently compromised.

Regarding the analysis of the psychometric properties, the results indicate that due to the large cultural differences among countries, some items may need a thorough study of cultural adaptation.

Considering the impact of epilepsy in the daily life of the patient, an assessment tool of the functionality of the patient with epilepsy, translated for its use in Brazil, can collaborate in assessing functionality, in the collection of data on its clinical evolution and in its use as a measure of clinical outcomes studies.

\section{References}

1. Hermann B, Jacoby A. The psychosocial impact of epilepsy in adults. Epilepsy Behavior. 2009;15(1 Suppl 1):11-6. https://doi.org/10.1016/j.yebeh.2009.03.029

2. Egland MJ, Liverman CT, Schultz AM, Strawbridge LM, editors. Epilepsy across the spectrum: promoting health and understanding. Washington: Nationals Academies; 2012.

3. Nickel R, Silveira NL, Souza JRB, Pinto LM, Robert C, Lima AP et al. [Descriptive study on the occupational performance of the subject with epilepsy: the use of the ICF as a tool for classification of activity and participation]. Acta Fisiatrica. 2011;18(2):55-60. Portuguese

4. Nickel R, Silvado CE, Germiniani FM, Paola L, Silveira NL, Souza JR et al. Quality of life issues and occupational performance of persons with epilepsy. Arq Neuropsiquiatr. 2012;70(2):140-4. https://doi.org/10.1590/S0004-282X2012000200013

5. Zanni KP, Bianchin MA, Marques LHN. Quality of life and occupational performance of patients undergoing epilepsy surgery. J Epilepsy Clin Neurophysiol. 2009;15(3):114-7. https://doi.org/10.1590/S1676-26492009000300004

6. Wang WH, Yu HY, Yen DJ, Lin YY, Kwan SY, Chen Cet al. The Social and Occupational Functioning Scale for Epilepsy (SOFSE): a brief mensure of functional status in a Taiwanese sample with epilepsy. Epilepsia. 2013;54(5):888-97. https://doi.org/10.1111/epi.12141

7. Fernandes PS. [Translation functionality scale for people with epilepsy (social and ocupational scale for epilepsy) for the portuguese - Brazil] [dissertation]. Curitiba: Universidade Federal do Paraná; 2015. Portuguese.

8. Beaton DE, Bombardier C, Guillemin F, Ferraz MB. Guideliness for the process of cross-cultural adaptation of self-report measures. Spine. 2000;25(24):3186-91. https://doi.org/10.1097/00007632-200012150-00014

9. Pasquali L. Análise factorial para pesquisadores. Brasilia: LabPAM; 2006.

10. Johnson RA, Wichern DW. Applied multivariate statistical analysis. 6th ed. Upper Saddle River: Prentice Hall; 2007.

11. Kaiser HF, Rice J. Little Jiffy, Mark IV. Educ Psychol Meas. 1974;34(1):111-7.
12. Alonso NB. Generic and específics instruments for assessing quality of life. In: Albuquerque M, Cukiert A, editors. Epilepsy and quality of life. São Paulo: Alaude; 2007.

13. Maroco J, Garcia-Marques T. Qual a fiabilidade do alfa de Cronbach? Questões antigas e soluções modernas? Labor Psicologia. 2006;4(1):65-90.

14. Cerniauskaite M, Ajovalasit D, Quintas R, Alvarez A, Franceschetti S, Casazza M et al. Functioning and desability in persons with epilepsy. Am J Phys Med Rehabil. 2012;91(13):22-30. https://doi.org/10.1097/PHM.0b013e31823d4d6f

15. Tella LMHG, Fonseca LC, Bertuqui CM. Epilepsia e trabalho. Rev Cien Med. 1996;5(3):113-8

16. Borges MA, Cordeiro JA, Delgado AS. Duration and age of epilepsy and its correlation with the job. Arq Neuropsiquiatr. 2000;58(2A):288-91.

17. Borges MA, Pissolati AF. [Migration in different sorts of work, unemployment and retirement of 81 epileptic patients: threeyear follow-up study]. Arq Neuropsiquiatri. 2000;58(1):107-11. Portuguese. https://doi.org/10.1590/S0004-282X2000000100016

18. Salgado PCB, Souza EAP. [Impact of epilepsy at work: evaluation of quality of life]. Arq Neuropsiquiatri. 2002;60(2B):444-5. Portuguese. https://doi.org/10.1590/S0004-282X2002000300019

19. Han K, Choi-Kwon S, Lee SK. Leisure time physical activity in patients with epilepsy in Seoul, South Korea. Epilepsy Behav. 2011;20(2):321-5. https://doi.org/10.1016/j.yebeh.2010.11.018

20. Motamedi M, Sahraian MA, Moshirzadeh S. A cross sectional study evaluating perceived impact of epilepsy on aspects of life. Zahedan J Res Med Sci. 2012;14(4):33-6.

21. Kobau R, Cu W, Kadima N, Zack MM, Sajatovic M, Kaiboriboon K. et al. Tracking psychosocial health in adults with epilepsy: estimates from the 2010 National Health Interview Survey. Epilepsy Behav. 2014;41:66-73. https://doi.org/10.1016/j.yebeh.2014.08.002

22. Koponen A, Seppälä U, Eriksson K, Nieminen P, Uutela A, Sillanpää M et al. Social functioning and psychological well-being of 347 young adults with epilepsy only: population-based, controlled study from Finland. Epilepsia. 2007;48(12):907-12. https://doi.org/10.1111/j.1528-1167.2007.01017.x 


\section{APPENDIX 1}

Final version of the functionality assessment tool for the person with epilepsy (SOFSE) in Portuguese.

(Versão original: Wang e col., 2013) (Versão traduzida: Fernandes, 2015).

Nome do Paciente:

Gênero:____ N No de Identificação/Identidade do Paciente:

Data de Nascimento:_________ Data:

Data: $1 / 1$

As perguntas abaixo têm a intenção de conhecer suas condições de vida cotidiana quando você não está em crise epiléptica. Por favor, preencha/assinale a resposta mais adequada para cada pergunta.

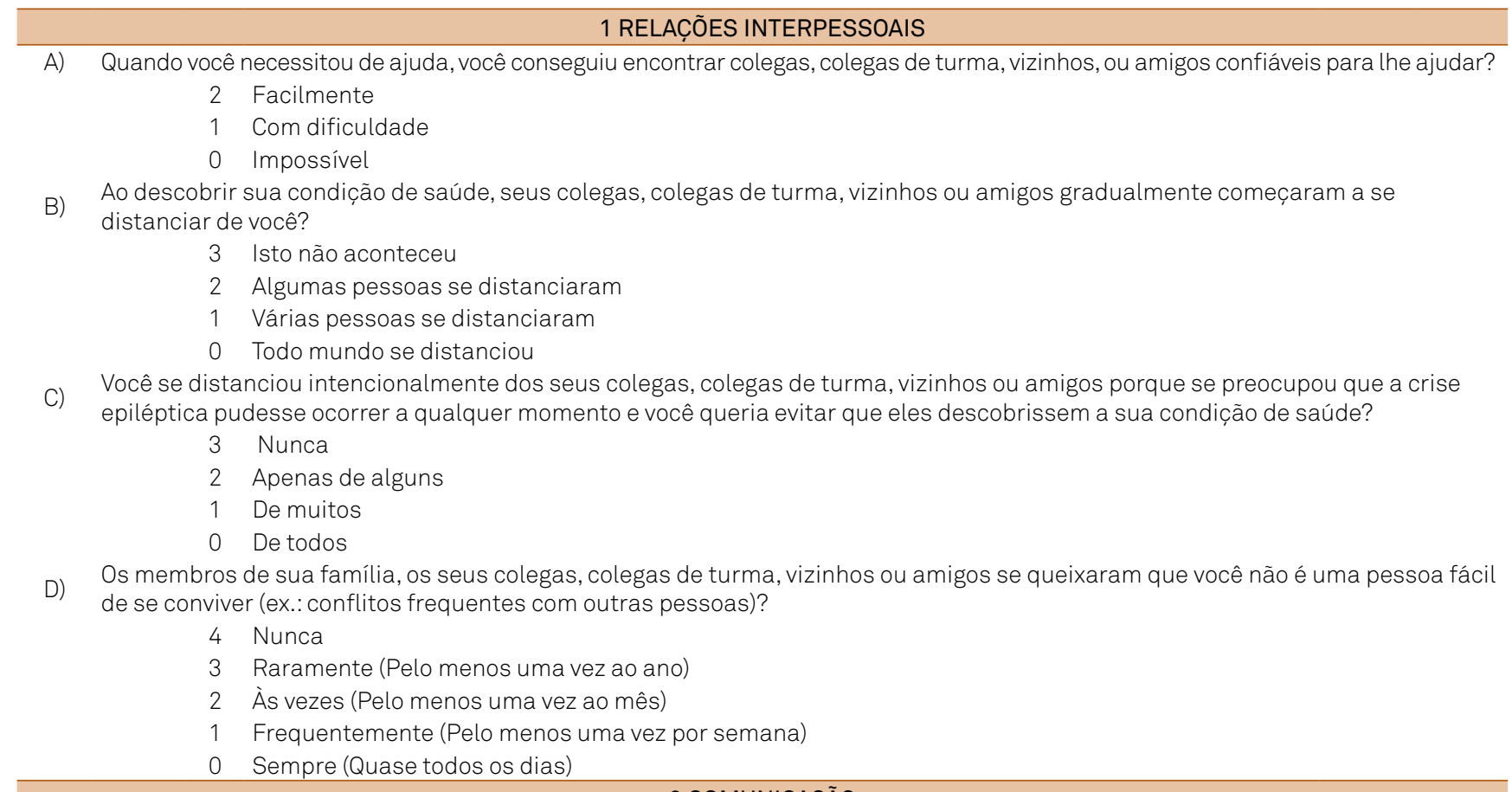

\section{COMUNICAÇÃO}

A) Quando alguém está compartilhando alguma informação com você, eles têm que repetir a informação (muitas vezes) para que você possa entendê-la completamente?
4 Nunca
3 Raramente (Pelo menos uma vez ao ano)
2 Às vezes (Pelo menos uma vez ao mês)
1 Frequentemente (Pelo menos uma vez por semana)
0 Sempre (Quase todos os dias)

B) Quando você está conversando com outras pessoas, elas se queixam de que não conseguem entender o que você está dizendo?

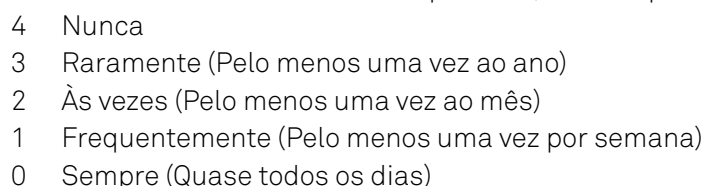

C) Quando você está conversando com outras pessoas, você demora bastante tempo para pensar nas palavras que você quer usar e às vezes não consegue lembrá-las?

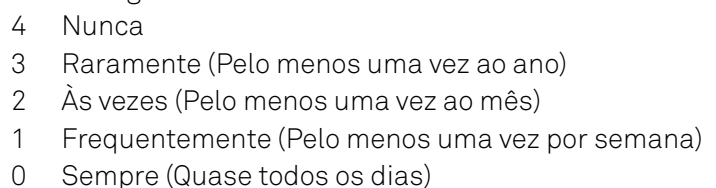

D) Quando você está conversando com outras pessoas, você fica tão emotivo (a) que não consegue continuar a conversa tranquilamente?
4 Nunca
3 Raramente (Pelo menos uma vez ao ano)
2 Às vezes (Pelo menos uma vez ao mês)
1 Frequentemente (Pelo menos uma vez por semana)
o Sempre (Quase todos os dias) 
Você participou das atividades listadas abaixo no ano passado?

A) Foi à casa de parentes ou amigos para uma reunião social e para conversar.

0 Não nos últimos 12 meses

1 Raramente (Pelo menos uma vez ao ano)

2 Às vezes (Pelo menos uma vez por mês)

3 Frequentemente (Pelo menos uma vez por semana)

B) Convidou parentes ou amigos para irem à sua casa para uma reunião social e para conversar.

0 Não nos últimos 12 meses

1 Raramente (Pelo menos uma vez ao ano)

2 Às vezes (Pelo menos uma vez por mês)

3 Frequentemente (Pelo menos uma vez por semana)

C) Conversou com parentes ou amigos pelo telefone ou online.

0 Não nos últimos 12 meses

1 Raramente (Pelo menos uma vez ao ano)

2 Às vezes (Pelo menos uma vez por mês)

3 Frequentemente (Pelo menos uma vez por semana)

D) Fez uma refeição, foi às compras, saiu pra cantar, assistiu a um filme ou viajou com outras pessoas.

0 Não nos últimos 12 meses

1 Raramente (Pelo menos uma vez ao ano)

2 Às vezes (Pelo menos uma vez por mês)

3 Frequentemente (Pelo menos uma vez por semana)

E) Participou de atividades organizadas por alguma associação, sociedade/clube (ex.: dança, atividade física), ou um grupo religioso.

0 Não nos últimos 12 meses

1 Raramente (Pelo menos uma vez ao ano)

2 Às vezes (Pelo menos uma vez por mês)

3 Frequentemente (Pelo menos uma vez por semana)

\section{ATIVIDADES DE LAZER}

*Se você não participou das atividades listadas abaixo no ano passado, por favor, dê o(s) motivo(s).

A) Exercícios dinâmicos, incluindo ciclismo, jogos com bola, natação, corrida e dança.

0 Não nos últimos 12 meses - Motivo:

1 Raramente (Pelo menos uma vez ao ano)

2 Às vezes (Pelo menos uma vez por mês)

3 Frequentemente (Pelo menos uma vez por semana)

B) Atividades de lazer ao ar livre, incluindo caminhada no campo, fazer compras, caminhada, pescaria e fotografia.

0 Não nos últimos 12 meses - Motivo:

1 Raramente (Pelo menos uma vez ao ano)

2 Às vezes (Pelo menos uma vez por mês)

3 Frequentemente (Pelo menos uma vez por semana)

Pratica outra atividade de lazer que não foi descrita nos itens acima? Qual?

\section{HABILIDADES INSTRUMENTAIS PARA VIDA DIÁRIA}

Por favor, avalie sua capacidade e frequência de execução dos seguintes itens e preencha a resposta correspondente.

\section{Capacidade:}

(2). Competente

(1). Necessita de assistência

(0). Incapaz de executar
Frequência:

(4). Diariamente

(3). Pelo menos uma vez por semana

(2). Pelo menos uma vez por mês

(1). Pelo menos uma vez ao ano

(0). Não nos últimos 12 meses

A) Sair de casa para fazer compras de forma independente, como fazer compras de mantimentos, ou necessidades diárias.

B) Administrar as tarefas de casa de forma independente, como arrumar seu quarto, lavar roupas, pagar contas e reparos domésticos.

Administrar suas três refeições diárias de forma independente: tanto cozinhando em casa ou telefonando para serviços de entrega de comida.

D) Andar de bicicleta, dirigir, ou utilizar o transporte público de forma independente para viajar para outra cidade.

E) Administrar suas finanças, incluindo uso de cartões, gastar o dinheiro corretamente e planejar o orçamento. 
Você está empregado atualmente?

*Sim (Período integral, autônomo, etc.)

Horas de trabalho/dia:

A) Suas horas de trabalho são:

3 Pelo menos 8 horas de trabalho em período integral

2 Pelo menos 4 horas de trabalho em meio período

1 Menos do que 4 horas de trabalho em meio período

B) Você está neste emprego atual há:

3 Mais de dois anos

$21-2$ anos

1 Menos de um ano

C) Seus colegas de trabalho têm se queixado que você frequentemente esquece ou negligencia tarefas ou compromissos importantes, e que o seu desempenho precisa melhorar?
4 Nunca
3 Raramente (Pelo menos uma vez ao ano)
2 Às vezes (Pelo menos uma vez ao mês)
1 Frequentemente (Pelo menos uma vez por semana)
0 Sempre (Quase todos os dias)

D) Você se sentiu tão deprimido (a) emocionalmente ou ansioso(a) que não foi capaz de trabalhar ou, teve mesmo que pedir licença do trabalho?
4 Nunca
3 Raramente (Pelo menos uma vez ao ano)
2 Às vezes (Pelo menos uma vez ao mês)
1 Frequentemente (Pelo menos uma vez por semana)
0 Sempre (Quase todos os dias)

E) O conteúdo do seu trabalho, oportunidades de promoção e salário tem sido limitado pela sua condição de saúde?
0 Sim
1 Não

*Não (inclui estar desempregado, ser estudante, dona de casa, aposentado(a) e voluntário(a)

A) Há quanto você está fora da escola, desempregado, ou incapaz de administrar os trabalhos domésticos?
3 Nunca
2 Menos de 6 meses
1 Menos de 1 ano
0 Mais de 1 ano

B) No ano passado, quantas vezes você não pôde trabalhar, ir à escola, ou realizar atividades diárias por alguns dias consecutivos por causa da epilepsia?

3 Nunca

2 Aconteceu uma vez

1 Aconteceu pelo menos duas vezes, ou tenho sempre ficado em casa descansando, mas consigo dar conta das atividades diárias de forma independente.

0 Tenho sempre ficado em casa descansando e preciso de assistência para as atividades diárias.

C) Você teve dificuldades de aprendizagem ou dificuldades diárias, por causa de problemas de memória, incluindo incapacidade para aprender novas informações, esquecimento de acompanhamentos e ingestão de novos medicamentos, e extravio de itens?
4 Nunca
3 Raramente (Pelo menos uma vez ao ano)
2 Às vezes (Pelo menos uma vez ao mês)
1 Frequentemente (Pelo menos uma vez por semana)
0 Sempre (Quase todos os dias)

Você se sentiu tão deprimido (a) emocionalmente, ou ansioso que seus estudos foram severamente afetados, ou sua vida diária foi completamente perturbada?
4 Nunca
3 Raramente (Pelo menos uma vez ao ano)
2 Às vezes (Pelo menos uma vez ao mês)
1 Frequentemente (Pelo menos uma vez por semana)
0 Sempre (Quase todos os dias)

E) Você está incapacitado de trabalhar ou continuar seus estudos? Você precisa de acompanhamento em longo prazo por causa da epilepsia?

$$
\begin{array}{ll}
0 & \text { Sim } \\
1 & \text { Não }
\end{array}
$$

I Você ficou com alguma dúvida em relação aos itens anteriores?

II Você não entendeu algum termo ou palavra nas questões acima?

III Gostaria de fazer alguma sugestão para melhorar a Escala? 
APPENDIX 2

Result of exploratory factor analysis. Não está citado no texto.

\begin{tabular}{|c|c|c|c|c|c|c|}
\hline \multicolumn{7}{|c|}{ Factor Loadings } \\
\hline \multirow{2}{*}{ Item } & \multicolumn{5}{|c|}{ Item } & \multirow{2}{*}{ Item } \\
\hline & 1 & 2 & 3 & 4 & 5 & \\
\hline ri1 & 0.2521 & 0.3798 & 0.2372 & 0.6998 & 0.1134 & 0.7413 \\
\hline ri2 & 0.1832 & 0.1371 & 0.0122 & 0.7762 & 0.0336 & 0.6969 \\
\hline ri3 & 0.3450 & 0.0555 & 0.0051 & 0.6237 & 0.1854 & 0.6188 \\
\hline ri4 & 0.1393 & 0.0779 & 0.1068 & 0.2475 & 0.4871 & 0.3164 \\
\hline $\mathrm{co1}$ & 0.8046 & 0.0312 & 0.0890 & 0.0618 & 0.0077 & 0.6776 \\
\hline $\mathrm{co} 2$ & 0.2415 & 0.4969 & 0.2182 & 0.2057 & 0.4170 & 0.6595 \\
\hline $\operatorname{co3}$ & 0.7046 & 0.1656 & 0.1226 & 0.0861 & 0.0727 & 0.5126 \\
\hline $\operatorname{co} 4$ & 0.5998 & 0.0735 & 0.0890 & 0.3970 & 0.3246 & 0.6252 \\
\hline as1 & 0.3322 & 0.0109 & 0.2080 & 0.1843 & 0.6372 & 0.5634 \\
\hline as2 & 0.1626 & 0.1233 & 0.1361 & 0.2616 & 0.6682 & 0.7473 \\
\hline as3 & 0.0152 & 0.2265 & 0.2670 & 0.0972 & 0.6734 & 0.6231 \\
\hline as4 & 0.1119 & 0.4314 & 0.1293 & 0.3788 & 0.4041 & 0.5032 \\
\hline as5 & 0.0581 & 0.4322 & 0.1092 & 0.0846 & 0.3521 & 0.3685 \\
\hline la1 & 0.1641 & 0.6497 & 0.0029 & 0.1045 & 0.2722 & 0.5139 \\
\hline la2 & 0.0306 & 0.6909 & 0.1595 & 0.1155 & 0.0444 & 0.4175 \\
\hline hi1 & 0.0514 & 0.0090 & 0.7967 & 0.2259 & 0.1805 & 0.6412 \\
\hline hi2 & 0.0462 & 0.0166 & 0.4721 & 0.2510 & 0.2451 & 0.6353 \\
\hline hi3 & 0.0186 & 0.5219 & 0.4790 & 0.1267 & 0.0022 & 0.5788 \\
\hline hi4 & 0.3184 & 0.0605 & 0.6389 & 0.0213 & 0.0672 & 0.4649 \\
\hline hi5 & 0.1049 & 0.0969 & 0.7830 & 0.1556 & 0.1228 & 0.6555 \\
\hline $\begin{array}{l}\text { Explained } \\
\text { variance }\end{array}$ & 0.1550 & 0.1270 & 0.100 & 0.0940 & 0.1010 & \\
\hline $\begin{array}{l}\text { Variance } \\
\text { accumulated }\end{array}$ & 0.1550 & 0.2830 & 0.3830 & 0.4770 & 0.5780 & \\
\hline Cronbach's Alpha & 0.5628 & 0.7019 & 0.6770 & 0.5534 & 0.6678 & \\
\hline Bartlett Test & 349,982 & & & & & \\
\hline $\mathrm{KMO}$ & 0.59 & & & & & \\
\hline
\end{tabular}

ri: interpersonal relationships; co: communication; as: social activities; la: leisure; hi: instrumental living skill. 
APPENDIX 3

Statistic analysis of dimension 6 .

\begin{tabular}{|c|c|c|c|}
\hline \multicolumn{4}{|c|}{ Occupation factor - dimension 6} \\
\hline \multicolumn{2}{|c|}{ Sample of workers } & \multicolumn{2}{|c|}{ Sample non workers } \\
\hline Item & Factor loading & Item & Factor loading \\
\hline A & 0.72 & A & 0.35 \\
\hline $\mathrm{B}$ & 0.73 & B & 0.72 \\
\hline C & 0.33 & C & 0.74 \\
\hline $\mathrm{D}$ & 0.55 & $\mathrm{D}$ & 0.77 \\
\hline$E$ & 0.01 & $E$ & 0.73 \\
\hline Cronbach's Alpha & 0.3406 & Cronbach's Alpha & 0.6948 \\
\hline Bartlett test & 6.235763 (p-valor: 0.7950817$)$ & Bartlett test & 32,63357 (p-valor: 0.0003) \\
\hline $\mathrm{KMO}$ & 0.49 & $\mathrm{KMO}$ & 0.59 \\
\hline
\end{tabular}

